\title{
Risk Evaluation and Leakage Mechanism on Runoff in Coal Mining Area-A Case Study in Jinjie Coal Mine of Tuwei River
}

\author{
Le BAI ${ }^{\mathrm{a}, \mathrm{b}, 1}$ Hongmou HE ${ }^{\mathrm{a}, \mathrm{b}}$, Shu LI ${ }^{\mathrm{a}, \mathrm{b}}$, Xinwei GUO ${ }^{\mathrm{a}, \mathrm{b}}$ and En-kuan LI ${ }^{\mathrm{a}, \mathrm{b}}$ \\ ${ }^{a}$ Yellow River Institute of Hydraulic Research, Zhengzhou, China \\ ${ }^{\mathrm{b}}$ Key Laboratory of the Loess Plateau Soil Erosion and Water Loss Process and \\ Control, Zhengzhou, China
}

\begin{abstract}
According to the aims of the runoff protection in coal mining area, taking Jinjie coal mine as an example, the risk zonation and mechanism of runoff leakage were carried out based on the dimen-sionless multi-factor information fusion technique. Based on the analysis of field exploration and borehole data, four key factors affecting the runoff leakage from the roof were identified, which included the deposition features of aquifer in Sala Wusu Group, the distribution of overburden rock and soil mass, effective thickness of aquiclude layer and the height of water flow cracking zone. The evaluation criterion was whether the development height of the water flow cracking zone reaches or exceeds the bottom plate of the sandy phreatic aquifer and even penetrates the surface ground, which results in the complete or partial leakage of the phreatic water. According the evaluation criterion, the influence of coal mining disturbance on runoff leakage was divided into three zones: zone of seriously runoff leakage, zone of general runoff leakage and zone of slight runoff leakage. Furthermore, the influence mechanism of different zones in coal mining also been discussed preliminarily, which included drainage Sarawusu aquifer, groundwater leakage in Sarawusu aquifer, water level fluctuation in Sarawusu aquifer and so on. Finally, classification pattern diagram was drawn.
\end{abstract}

Keywords. Runoff, the danger division and evaluation, salawusu formation, coal mining

\section{Introduction}

Since the 1980s, development of High Intensity Coal Resources in Northern Shaanxi, artificial collateral circulation was produced in the original natural water cycle [1], laeakage of groundwater and river runoff, groundwater level recession, river runoff less and other phenomena appear in this area. River runoff is an important part of water resources, carrying most of the good ecological environment and human agriculture and domestic water in this area. The runoff leakage in coal mining area destroys the original dynamic balance in natural state, with the extension of mining time, the increase of the scope, the increase of leakage amount, the original production and flow conditions, time-history rules and water resources development and utilization conditions are constantly changing. The study on the risk and mechanism of river

\footnotetext{
${ }^{1}$ Le Bai, Yellow River Institute of Hydraulic Research, Zhengzhou, China; E-mail: 76916968@qq.com.
} 
runoff leakage has become one of the hot and difficult problems in the process of coal mining in northern Shaanxi and the protection of scarce water resources in arid and semi-arid areas.

It has been proved that coal mining in northern Shaanxi does have an impact on river runoff [2], For a long time, many scholars have calculated the influence ratio and influence quantity of coal mining on river runoff according to the change of river runoff and base flow, using theoretical calculation and model simulation methods [3-7]. Groundwater is closely related to river runoff in northern Shaa nxi, scholars have studied the influence of coal mining on groundwater from engineering geological background, groundwater dynamic change, spring discharge attenuation and groundwater change [8-12], and further affirmed the significance of groundwater leakage. Wang Shuangming [13-15] and other scholars give the ecological water level protection zone based on coal mining safety from the point of view of coal mining. However, from the point of view of river runoff protection, the risk zoning of river runoff leakage in high strength coal mining area is carried out, and the influence mechanism and leakage mode of leakage risk are explained less. At present, there is no systematic research result. Therefore, this paper takes Jinjie Coal Mine in Tuwei River Basin as an example, through the extraction of key factors, the formulation of evaluation criteria, the determination of river runoff leakage risk, summarize and summarize the leakage mechanism of different zones, providing technical support for sustainable development and utilization of water resources in watersheds.

\section{Research Area Survey}

Tuwei River is a tributary on the right bank of the middle reaches of the Yellow River, and it is also an important water source for industrial and agricultural production, living and ecological environment maintenance in Shenmu County. As an important part of Yushen mining area, the Tuwei River basin is rich in coal resources, which is characterized by shallow burial, good mining conditions and superior coal quality. But it is located in the Mu Us Desert and the northern Shaanxi Loess Plateau border area, the average annual precipitation is $377.4 \mathrm{~mm}$, water surface evaporation $1179.3 \mathrm{~mm}$ (E601), it belongs to the semi-arid region, water resources are short and the ecological environment is fragile.

Jinjie Coal Mine-Budwei River Basin is currently mining the first pair of tens of millions of tons of large backbone mines. From top to bottom, the stratigraphic profiles are: $\mathrm{Q}_{4}{ }^{\mathrm{aL}}, \mathrm{Q}_{3 \mathrm{~S}},(10-40 \mathrm{~m}), \mathrm{Q}_{21},(20-60 \mathrm{~m}), \mathrm{N}_{2 \mathrm{~b}}(40-100 \mathrm{~m}), \mathrm{J}_{2 \mathrm{Z}}(45-140 \mathrm{~m})$, coal seam normal bedrock. $3^{-1}$ Coal seam depth $70-120 \mathrm{~m}$, the basic whole area can be mined, is the stable coal seam, is also the mining area advance mining coal seam. Groundwater in the basin is mainly pore fissure water of Sarawusu Formation with strong water content, the thickness is about $40-60 \mathrm{~m}$, which mainly receives precipitation infiltration recharge and drains to the surface in the form of spring. Development of two long-term gully flow in the mine field-Qingcaojie ditch and Heze ditch, Qingcaojie ditch flows in the south of the mine field is $21417.7 \mathrm{~m}^{3} / \mathrm{d}$, Average flow rate of Heze ditch is $9832.3 \mathrm{~m}^{3} / \mathrm{d}$, which is closely related to the flow force of the surface river. 


\section{Key Factors and Evaluation Criteria}

In the process of river runoff leakage risk assessment and leakage mechanism research, the selection of zoning factors and the establishment of evaluation criteria are very important, which not only need to consider the accessibility of evaluation indicators, but also make the criteria have strong maneuverability [16]. The main information of river runoff leakage under coal mining conditions is described by as few key factors as possible, which makes the evaluation results more realistic.

The following 4 conditions must be met for runoff leakage: (1) unconfined aquifer with certain occurrence characteristics; (2) Composite distribution characteristics of overlying rock and soil; (3) Necessary water diversion space; (4) Effective waterresisting thickness.we chose characteristics of aquifer occurrence in Salawusu Formation, composite characteristics of overlying rock and soil, height of water flowing fractured zone and effective water-resisting thickness as key factors to study the risk zoning of coal mining for river runoff leakage.

\subsection{Characteristics of Aquifer Occurrence in Sarawusu Formation}

The groundwater of the Sarawusu formation in the study area is mainly distributed in the Qingcaojie ditch basin and the Heze ditch basin, which is one of the main aquifers in the mine field. The buried depth of groundwater level is less than $3 \mathrm{~m}$, the annual variation of groundwater level is $1-1.5 \mathrm{~m}$, the unit water inflow is $0.116-1.2 \mathrm{~L} / \mathrm{s} \cdot \mathrm{m}$, the water rich is medium to strong. The maximum flow of spring water from the aquifer was $304 \mathrm{~L} / \mathrm{s}, \mathrm{K}=1.27-14.822 \mathrm{~m} / \mathrm{d}$. The phreatic water of Sarawusu Formation in the region mainly receives atmospheric precipitation recharge (permeance coefficient 0.10 $0.60)$, , spring excretion is the main, followed by evaporation and vertical excretion, the occurrence characteristics of phreatic water in Sarawusu Formation affect the discharge of Qingcaojie ditch and Hezigou ditch.

\subsection{Overlying Strata Combination Characteristics}

The spatial assemblage of rock and soil above coal seam is the basis of the deformation and failure of overburden rock after coal seam mining, which has an important influence on the degree of deformation and failure of overlying strata after coal seam mining, that is, the significant impact of "three zones" development height [17]. The degree of damage is directly related to the protection and utilization of phreatic water in the Sarawusu Formation, and even affects the evolution of runoff in the Tuwei River.

According to the overlying strata spatial distribution and combination morphology in $3^{-1}$ coal seam of Jinjie Coal Mine, and complexity of spatial occurrence of aquifer, and differences in the impact of coal mining on aquifer, the combination of coal seam and aquifer in the study area is divided into three categories, and seven different subclasses are subdivided in each category.

\subsection{Height of Water Flowing Fractured Zone}

According to the statistics of 124 boreholes in Jinjie mine field, (Coordinates, elevation, sand layer thickness, soil layer thickness, coal seam overlying bedrock thickness, etc). Using the fitting formula of Professor Li W P [18] to calculate the development height of water-conducting fissure zone, that is: 


$$
H=9.59 M+13.55
$$

In the formula: The $H$ is the height of fracture development, $\mathrm{m}$; the $M$ is the height of coal seam mining, m. Applying Kriging interpolation method, the contour map of the development height of the water-conducting fissure zone in the first coal seam $3^{-1}$ is obtained. Development height of water-conducting fissure zone is $27.84 \mathrm{~m}-48.17 \mathrm{~m}$ in minefield area, the developmental height increases from northwest to southeast, fracture ratio 13-19, see figure 1 for details.

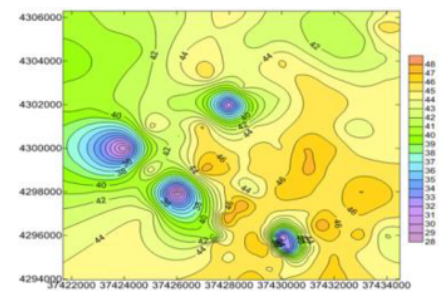

Figure 1. The height of water flowing fractured zone.

\subsection{Effective Water-Resisting Thickness}

The aquifuge layer is the direct bottom plate of the phreatic water of the Sarawesu Formation, its spatial distribution features (thickness and continuity), the change of permeability after mining directly affects the change of phreatic water position of Sarawesu Formation. This paper defines the distance $(\triangle \mathrm{h})$ between the $3^{-1}$ coal of the main coal seam and the bottom plate of the aquifer of the Sarawusu Formation minus the height $(\mathrm{H})$ of the water conduction fissure zone formed by the total height of the primary mining as the effective aquifer thickness $(\mathrm{He})$. Then the effective waterresisting thickness is expressed as follows:

$$
H e=\triangle h-H
$$

Contrasting the distance between the development height of water-conducting fissure zone and the bottom plate of unconfined aquifer of Salausu Formation, areas with a value greater than 0 (positive) are safe areas, less than 0 (negative value) is a non-safe area, that is, a dangerous area, see figure 2(a), figure 2(b).

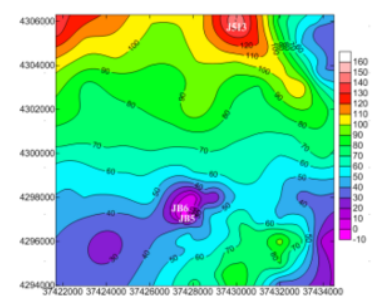

(a) The height of the water flowing fractured zone from surface

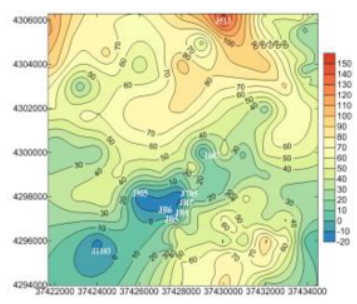

(b) The height of water flowing fractured zone from bottom of Sala Wusu group aquifer

Figure 2. The height of the water flowing fractured zone from the surface and the bottom of Sala Wusu group aquifer. 
Figure 2(a) shows that: after $3^{-1}$ coal seam mining, the height of water flowing fractured zone is $-3.50 \mathrm{~m}-152 \mathrm{~m}$ from the ground, concentrated on $50-100 \mathrm{~m}$, up to $151.78 \mathrm{~m}$ (figure 2(a) Color 150-160m area), only in JB5 and JB6(the area where color $-10 \mathrm{~m}-0 \mathrm{~m}$ in figure 2(a) is located), the height of water flowing fractured zone of JB5 and JB6 heights $2.73 \mathrm{~m}$ and $3.50 \mathrm{~m}$ above ground. On the whole, the distance between the height of water flowing fractured zone and the ground gradually increases from south to north, among them, the height of water flowing fractured zone is $-10 \mathrm{~m}-20 \mathrm{~m}$ from the ground in the area of Qingcaojie Valley, at the northeast corner of the mine field, the distance between the height of water flowing fractured zone and the ground is $40 \mathrm{~m}-60 \mathrm{~m}$ in the Heze ditch basin, 10-40m distance from surface to water-conducting fissure zone in southeast corner of minefield.

Figure 2(b) shows that: the height of water flowing fractured zone is $-20 \mathrm{~m}-149 \mathrm{~m}$ from the height of bottom plate of Sarawsu Formation, to concentrate on 20m-90m, up to $148.05 \mathrm{~m}(\mathrm{~J} 513$ is maximum point, the area where color $140 \mathrm{~m}-150 \mathrm{~m}$ in figure 2 (b) is located), within J607- J905- J1103- J705-JB7-JB1-JB6-JB5 (region in figure 2(b) $20 \mathrm{~m}-0 \mathrm{~m})$ the height of water flowing fractured zone in the area exceeds $3.84 \mathrm{~m}-19.99 \mathrm{~m}$ of bottom plate of Sarawasu Formation. Basically, from the Qingcaojie ditch, the height of water flowing fractured zone increases from the bottom plate of Sarawusu Formation, among them, the height of water flowing fractured zone south of Qingcaojie ditch is $40 \mathrm{~m}-70 \mathrm{~m}$ from the bottom plate height of Sarawusu Formation, 50 $\mathrm{m}-80 \mathrm{~m}$ north of the Qingcaojie ditch. Height of bottom plate of Sarawusu Formation is less than $30 \mathrm{~m}$ from the south-east and southwest corner of the upper reaches of Heze ditch.

\section{Partitioning Results}

According to the above zoning factors and zoning standards, Jinjie coal mining area is generated after $3^{-1}$ coal seam mining, the different influence mechanism of Jinjie coal mining on river runoff is expounded, and the classification pattern map is drawn.

Severely affected areas: This area is strongly affected by mining, during normal mining, the water-conducting fissure penetrates directly into the aquifer of the Sarawusu Formation, the aquifer of Sarawusu Formation is drained, and then the river runoff is affected. The area is mainly distributed in the southwest corner of the lower reaches of Qingcaojie ditch and Heze ditch, followed by the northwest corner of the mine field, area about $23.46 \mathrm{~km}^{2}, 16.55 \%$ of minefield area.

(2) General affected areas : Under normal mining conditions, the pore phreatic water of the Quaternary Sarawusu Formation will increase the downward permeability and permeability, it may affect the groundwater flow field, lead to the leakage of phreatic water resources, and even reduce the flow rate of spring, coal mining will not lead to the regional decline of groundwater level, to some extent affect river runoff, belong to the general area. The area is mainly distributed in the south-central region of the mine field, followed by the lower reaches of Heze ditch, area about $37.27 \mathrm{~km}^{2}$, $26.29 \%$ of mine area.

(3) Slight affected areas: Coal mining in this area will not cause damage to the Quaternary unconfined aquifer, but only the fluctuation of the phreatic water level of the Quaternary Sarawusu Formation, the groundwater table can be recovered in a certain time, and the influence on the river runoff is slight. This area is mainly distributed in the vast area of the north-central part of the mine field, followed by the 
smaller area of the south-central-east part of the mine field, area about $81.04 \mathrm{~km}^{2}$, $57.16 \%$ of mine area.

\section{Conclusion}

(1) The characteristics of aquifer occurrence, the distribution of overlying rock and soil assemblage, the effective water-resisting thickness and the height of water flowing fractured zone of Sarawusu Formation are taken as the zoning factors, it is comprehensively determined whether the development height of the fissure zone of water diversion reaches or exceeds the bottom plate of the Quaternary phreatic waterbearing rock formation or even runs through the ground, resulting in complete or partial leakage of phreatic water as the zoning standard, the effect of coal mine opening on river runoff is divided into three areas, namely, severely affected areas, general affected areas and slight affected areas.

(2) The height of water flowing fractured zone is $27.84 \mathrm{~m}-48.17 \mathrm{~m}$ in minefield area, the height of water flowing fractured zone increased from northwest to southeast, and the fracture-mining ratio was 13-19. After $3^{-1}$ coal seam mining, the height of water flowing fractured zone is $-3.50 \mathrm{~m}-152 \mathrm{~m}$ from the ground, concentrated $50-100 \mathrm{~m}$, up to $\mathrm{m} 151.78 \mathrm{~m}$, the distance from the ground gradually increases from south to north, the height of water flowing fractured zone of water diversion is between $-20 \mathrm{~m}-149 \mathrm{~m}$ from the height of the bottom plate of Sarawusu Formation, mainly concentrated in $20 \mathrm{~m}$ $90 \mathrm{~m}$, up to $148.05 \mathrm{~m}$. Taking the Qingcaojie ditch as the boundary direction, theheight of water flowing fractured zone is increasing from the bottom plate of Sarawusu Formation.

(3) After the mining of $3^{-1}$ coal seam in Jinjie Coal Mine, the severely affected areas are mainly distributed in the southwest corner of the lower reaches of Qingcaojie ditch and Heze ditch; the general affected areas are mainly distributed in the southcentral region of the mine field, and the slight affected areas are mainly distributed in the north-central region of the mine field. Area of each division is $23.46 \mathrm{~km} 2,37.27 \mathrm{~km} 2$, $81.04 \mathrm{~km}^{2}$, the proportion of mine area is $16.55 \%, 26.29 \%$ and $57.16 \%$ respectively. The influence mechanisms of different zones are as follows: dewatering Sarawusu Formation, groundwater leakage in the Sarawsu Formation, volatility of aquifer water level in Sarawesu Formation and so on.

\section{Acknowledgements}

This paper is Supported by the National Key Research and Development Program of China (2017 YFC0403604); Special funds for basic scientific Research Operating Expenses of Central Public Welfare Research Institutes (HKY-JBYW-2019-05); Supported by the National Natural Science Foundation of China (51809103).

\section{References}

[1] Sun ZF, Wang SY, et al. Driving force analysis of runoff attenuation in tuwei river basin. Journal of Natural Resources. 2017 Feb; 32(2): 310-320. 
[2] Li T, Wang SJ, et al. Ecological significance and method to design protective coal pillar on surface runoff in desert shoal area. Journal of Mining \& Safety Engineering. 2016 Jan; 33(01): 134-140.

[3] Wu XJ, Dong Y. Recognition of runoff changes in mining area based on SWAT model. Environmental Science \& Technology. 2018 Jun; 41(6): 175-180.

[4] Bai L, Li HE and He HM. Assessing the impacts of precipitation and human activities on base flow in the middle Tuwei River Basin of the Yellow River. Journal of Natural Resources. 2014 Dec; 29(12): 2078-2087.

[5] Wang QM, Liu J, Sun J, Yang J. Temporal changes in annual runoff of typical rivers in Yu-Shen-Fu mining area and influential factors. Journal of Arid Land Resources and Environment. 2018 Mar; 32(4): 113-119.

[6] Wu XJ, Li H, Dong Y. Quantitative identification of coal mining and other human activities on river runoff in northern Shaanxi region. Acta Scientiae Circum-stantiae. 2014 Mar; 34(3): 772-780.

[7] Zhang SF, Ma C, Zhang L. The regulators of runoff of the Ulan Moron River in the Daliuta mine area: The effects of mine coal. Acta Scientiae Circumstantiae. 2011 Apr; 31(4): 889-896.

[8] Fan LM. Under groundwater seepage caused by coal mining and its prevenment and control measures in North Shaanxi Region. Mining Safety \& Environmental Protection. 2007 Oct; 34(5): 62-64.

[9] Fan LM, Jiang ZQ. Engineering geologic background of coal mining under water-containing condition in Yushen coal mining area. Coal Geology \& Exploration. 2004 Oct; 32(5): 32-35.

[10] Tao H, Ning KB, Tao FP, et al. Shalow groundwater dynamic characteristics and response to coal mining in the typical blown-sand region of the Northern Shaanxi Province. Journal of China Coal Society. 2016 Sep; 41(9): 2319-2325.

[11] Ji RJ, Peng SP, Fan LM, et al. Effect of coal exploita-tion on groundwater circulation in the Shen-Fu mine. Journal of China Coal Society. 2015 Apr; 40(4): 938-943.

[12] Fan LM, Xiang MX, Peng J, et al. Evolution analysis on springs in contiguous area of Maowusu Desert and Loess Plateau. Journal of China Coal Society. 2018 Jan; 43(1): 207-218.

[13] Fan LM, Ma XD, Ji RJ. The progress of research and engineering practice of water-preserved coal mining in western eco-environment frangible area. Journal of China Coal Society. 2015 Aug; 40(8): 1711-1717.

[14] Huang QX, Fan LM , et al. Study onoverburden aquclude and water protection mining regionazation in the ecological fragile mining area. Journal of China Coal Society. 2010 Jan; 35(1): 7-14.

[15] Wang SM, Huang QX, Fan LM, et al. Coal Mining and ecological water level protection in ecologically fragile areas. Coal Geology in China. $2011 \mathrm{Feb} ; 23(02): 31$.

[16] Fan LM, Ma XD, Jiang H, et al. Risk evaluation on water and sand inrush in ecologically fragile coal mine. Journal of China Coal Society. 2016 Mar; 41(3): 531-536.

[17] Qian YP, Jiang XH, Jin SY, et al. Analysis on the characteristic and variation of bade flow in loess plateau of the middle reaches of Yellow River. Journal of Earth Sciences and Environment. 2004 Jun; 26(2): 88-91.

[18] Chang JY, Li WP, Li T, Du PP. Zonation of water resources leakage due to coal mining in Shennan mining area. Coal Geology \& Exploration. 2011 Oct; 39(05): 41-45+51. 